\title{
SOME NEW SPECIES OF THYRIDIDAE.
}

\author{
BY R. J. WEST. \\ (Published by permission of the Trustees of the British Museum.)
}

\section{Striglina synethes sp.n.}

๙. Palpus sayal brown. Antenna minutely ciliate. Head: frons and vertex sayal brown. Thorax: patagium and tegula sayal brown. Abdomen sayal brown, venter light buff tinged with sayal brown. Pectus light buff. Legs sayal brown, fuscous on tibia and tarsus of foreleg. Forewing sayal brown, strigulate with fuscous, a small fuscous spot on discocellulars, an oblique, fuscous line from vein 6 subterminally to inner margin medially. Hindwing concolorous with forewing, an oblique line forming continuation of that on forewing; subterminally, a fuscous spot between veins 5 and 6 . Underside similar to upperside with fuscous spots more prominent.

Expanse $28 \mathrm{~mm}$. (tip to tip $25 \mathrm{~mm}$.).

Holotype ô: 28.xii.1912, paratype ô: 30.vi.1913, Philippine Is., Luzon I., subprov. Benguet, Palali, 2,000 ft.

Nearest ally: S. divisata Warr.

\section{Betousa penestica sp.n.}

․ Palpus light buff. Antenna minutely ciliate. Head: frons and vertex light buff. Thorax: patagium and tegula light buff. Abdomen light buff tinged with livid brown, venter light buff. Pectus and legs light buff. Forewing glossy, light buff, faintly strigulate with warm blackish brown, a prominent blackish brown spot in apical area. Hindwing similar in colour and markings to forewing, but having a tinge of livid brown on inner margin. Underside similar to upperside, with markings more strongly defined; a thickly scaled, warm buff streak through upper half of cell and just beyond on the forewing.

Expanse $21 \mathrm{~mm}$. (tip to tip $20 \mathrm{~mm}$.).

Holotype 우 : 2 . vii.1913, Philippine Is., Luzon I., subprov. Benguet, Palali, $2,000 \mathrm{ft}$.

Nearest ally : B. subrosealis Leech.

\section{Brixia hyphaema sp.n.}

§. Palpus light buff. Antenna ciliate. Head: frons and vertex light buff. Thorax: patagium and tegula light buff. Abdomen light buff above and beneath. Pectus and legs light buff. Forewing light buff tinged with fuscous on proximal half up to postmedial ; postmedial fascia consisting of a fuscous band obliquely incurved from costa to base of vein 6 , straight to vein 2 , then inwardly oblique to inner margin ; subterminal fascia consisting of a short fuscous band, obliquely excurved from end of postmedial on costa to termen at vein 5 , below this band two wavy streaks, the lower one finishing at tornus. Hindwing concolorous with forewing, an oblique fascia across middle of wing forming continuation 
of postmedial on forewing. Underside similar to upperside, markings more defined.

Expanse $20 \mathrm{~mm}$. (tip to tip $19 \mathrm{~mm}$.).

ㅇ. Similar to $\hat{0}$.

Expanse $23 \mathrm{~mm}$. (tip to tip $21 \mathrm{~mm}$.).

Holotype ô: 14.viii.1896, Japan, Shikoku, prov. Iyo, Komatsu ; allotype 우: 8.viii.1895, Kyushu, prov. Satsuma, Kure ; paratypes 1 ô: 3.vii.1895, 1 \&: 3.ix.1895, Kyushu, prov. Osumi, Tarumiza.

Nearest ally : B. emblicalis Moore.

\section{Brixia phaula sp.n.}

๙. Palpus avellaneous. Antenna apparently simple. Head: frons and vertex avellaneous. Thorax: patagium and tegula avellaneous. Abdomen light buff suffused with avellaneous, venter light buff. Pectus light buff. Legs light buff suffused with avellaneous, tarsi avellaneous, light buff at joints. Forewing glossy, light buff covered with a network of avellaneous and fuscous lines, avellaneous along costa ; subbasal fascia consisting of an avellaneous line slightly excurved; antemedial fascia consisting of an avellaneous line slightly incurved from costa to median nervure, angled, then slightly incurved to inner margin ; postmedial fascia consisting of an inwardly oblique, fuscous line. Hindwing concolorous with forewing, antemedial fascia fuscous, inwardly oblique ; postmedial fascia obliquely incurved from costa to vein 3 near termen, then inwardly oblique and wavy to inner margin near tornus. Underside similar to upperside, with lines in a suffusion of russet.

Expanse $28 \mathrm{~mm}$. (tip to tip $26 \mathrm{~mm}$.).

Holotype ô: 8.iv.1912, Philippine Is., Luzon I., subprov. Benguet, Klondyke, $800 \mathrm{ft}$.

Nearest ally : B. ypsilon Warr.

\section{Brixia erythroides sp.n.}

§. Palpus ochraceous-tawny, suffused with fuscous. Antenna minutely ciliate. Head: frons and vertex ochraceous-tawny. Thorax: patagium and tegula cartridge-buff suffused with fuscous. Abdomen cartridge-buff above and beneath, with lateral suffusion of fuscous to Brazil red, anal tuft ochraceoustawny mixed with Brazil red. Pectus cartridge-buff. Legs cartridge-buff lightly suffused with fuscous, tarsi suffused with fuscous, cartridge-buff at joints. Forewing Brazil red on proximal half diffusing into ochraceous-tawny on distal half, cartridge-buff on costa, a fuscous suffusion from base dividing into two streaks, one along subcosta, the other along median nervure, fringe fuscous edged with cartridge-buff. Hindwing Brazil red, fringe fuscous edged with cartridge-buff. Underside: fore- and hindwings, ground colour similar to upperside, irrorated with metallic pale blue scales forming transverse bands defined by fuscous, more prominent on hindwing.

Expanse $28 \mathrm{~mm}$. (tip to tip $26 \mathrm{~mm}$.).

Holotype ô : 2.vii.1913 ; paratype ô : 3.vii. 1913, Philippine Is., Luzon I., subprov. Benguet, Palali, 2,000 ft.

Nearest ally: B. uniformis Hmpsn. 


\section{Brixia plinthochroa sp.n.}

๙. Palpus first segment white, second segment army brown mixed with white, third segment army brown. Antenna minutely ciliate. Head: frons and vertex ferruginous suffused with army brown. Thorax: patagium and tegula ferruginous suffused with army brown. Abdomen ferruginous lightly suffused with army brown, venter cartridge-buff. Pectus cartridge-buff. Legs ferruginous suffused with army brown. Forewing ferruginous tinged with fuscous, cartridge-buff patches on costa, covered with faint, wavy, fuscous, transverse lines, interneural fuscous-black spots on termen. Hindwing similar to forewing, with a prominent fuscous-black spot on discocellulars. Underside : forewing ferruginous, with transverse series of army brown patches; a patch of fuscous-black and whitish raised scales in cell, three fuscous-black streaks from discocellulars along veins 6,7 , and 8 , strigulate with fuscous-black in subterminal area ; hindwing light buff with transverse series of ferruginous patches, strigulate with fuscous-black.

Expanse $32 \mathrm{~mm}$. (tip to tip $30 \mathrm{~mm}$.).

Holotype ô: 30.v.1914; paratypes 1 ô: 15.v., 1 ô: 29.v.1914, Philippine Is., Mindanao I., subprov. Lanao, Kolambugan (plains).

Nearest ally : B. uniformis Hmpsn.

\section{Brixia lipara sp.n.}

๙ิ. Palpus bay. Antenna minutely ciliate. Head: frons and vertex ochraceous-buff suffused with bay. Thorax: patagium and tegula ochraceousbuff suffused with bay. Abdomen ochraceous-buff above and beneath. Pectus ochraceous-buff. Legs ochraceous-buff suffused with bay. Forewing ochraceousbuff with a number of fine, transverse, wavy, bay lines; a streak of white on costa densely irrorated with bay (increasing in width toward apex) in which is a wide, bay, $\mathrm{V}$-shaped mark above discocellulars, the point reaching to below vein 6 , a bay patch at apex. Hindwing concolorous with forewing, but lightly suffused with bay on distal half. Underside similar to upperside, but markings more defined.

Expanse $34 \mathrm{~mm}$. (tip to tip $32 \mathrm{~mm}$.).

ㅇ. Similar to $\hat{\sigma}$.

Expanse $38 \mathrm{~mm}$. (tip to tip $36 \mathrm{~mm}$.).

Holotype ô: 21.xii.1911 ; allotype 우 : 17.iv .1912, Philippine Is., Luzon I., subprov. Benguet, Klondyke, $800 \mathrm{ft}$.

Nearest ally : B. atripunctalis Wlk.

\section{Brixia allocota sp.n.}

๙. Palpus white, fuscous above. Antenna minutely ciliate. Head: frons white, a triangular fuscous patch on upper half, vertex white, fuscous patch in middle. Thorax: patagium and tegula white. Abdomen white above and beneath. Pectus white. Legs white, with fuscous patches. Forewing glossy, white, a series of fuscous lunules on costa, three fuscous spots on inner margin, the proximal one small, the next a little larger, the distal one, large, oval, and placed obliquely, interneural spots on termen. Hindwing concolorous with 
forewing, interneural spots on termen, a spot on inner margin at one half. Underside: fore- and hindwings, glossy, white.

Expanse $38 \mathrm{~mm}$. (tip to tip $36 \mathrm{~mm}$.).

Holotype ô: 16.vi.1913, Philippine Is., Luzon I., subprov. Benguet, Baguio, 5,000 ft.

Nearest ally : B. pudicola Guen.

\section{Brixia polyterpes sp.n.}

o. Palpus fuscous, white inwardly and at joints. Antenna minutely ciliate. Head: frons and vertex fuscous tinged with old rose. Thorax: patagium fuscous, tegula fuscous, white posteriorly, rest of thorax white. Abdomen white above and beneath, some old rose spots laterally. Pectus white. Legs: coxae, femora and tibiae white with patches of old rose, tarsi fuscous, white at joints. Forewing glossy, white, faintly strigulate with old rose, a suffusion of fuscous on proximal third of costa. Hindwing glossy, white, subbasal fascia consisting of an oblique old rose line ; postmedial fascia consisting of an old rose band formed by a number of interlaced, old rose lines. Underside : forewing white, suffused over the greater part with ochraceous-buff, veins old rose ; irrorated with old rose below costa on proximal half, cell filled with raised scales irrorated with fuscous-black and metallic white; hindwing similar to upperside.

Expanse $30 \mathrm{~mm}$. (tip to tip $28 \mathrm{~mm}$.).

Holotype ô : 2. vii.1913, Philippine Is., Luzon I., subprov. Benguet, Palali, $2,000 \mathrm{ft}$.

Nearest ally : B. separata Warr. 


\section{$2 \mathrm{BHL}$ Biodiversity Heritage Library}

West, R. J. 1932. "Some new species of Thyrididae." Novitates zoologicae : a journal of zoology in connection with the Tring Museum 38, 7-10. https://doi.org/10.5962/bhl.part.14739.

View This Item Online: https://www.biodiversitylibrary.org/item/22934

DOI: https://doi.org/10.5962/bhl.part.14739

Permalink: https://www.biodiversitylibrary.org/partpdf/14739

\section{Holding Institution}

Natural History Museum Library, London

\section{Sponsored by}

Natural History Museum Library, London

\section{Copyright \& Reuse}

Copyright Status: In copyright. Digitized with the permission of the rights holder.

Rights Holder: The Trustees of the Natural History Museum, London

License: http://creativecommons.org/licenses/by-nc-sa/4.0/

Rights: http://biodiversitylibrary.org/permissions

This document was created from content at the Biodiversity Heritage Library, the world's largest open access digital library for biodiversity literature and archives. Visit BHL at https://www.biodiversitylibrary.org. 